\title{
Teaching Video NeuroImages: Atypical childhood epilepsy with centrotemporal spikes
}

\section{Seizures often discussed, rarely seen}

Egidio Spinelli, MD, Khrystyna Moskalyk, BS, REEG T, CLTM, and Sunita N. Misra, MD, PhD

Neurology ${ }^{\circledR}$ 2019;93:e2308-e2309. doi:10.1212/WNL.0000000000008637

Figure EEG stereotyped right > left centrotemporal spike waves

A

B

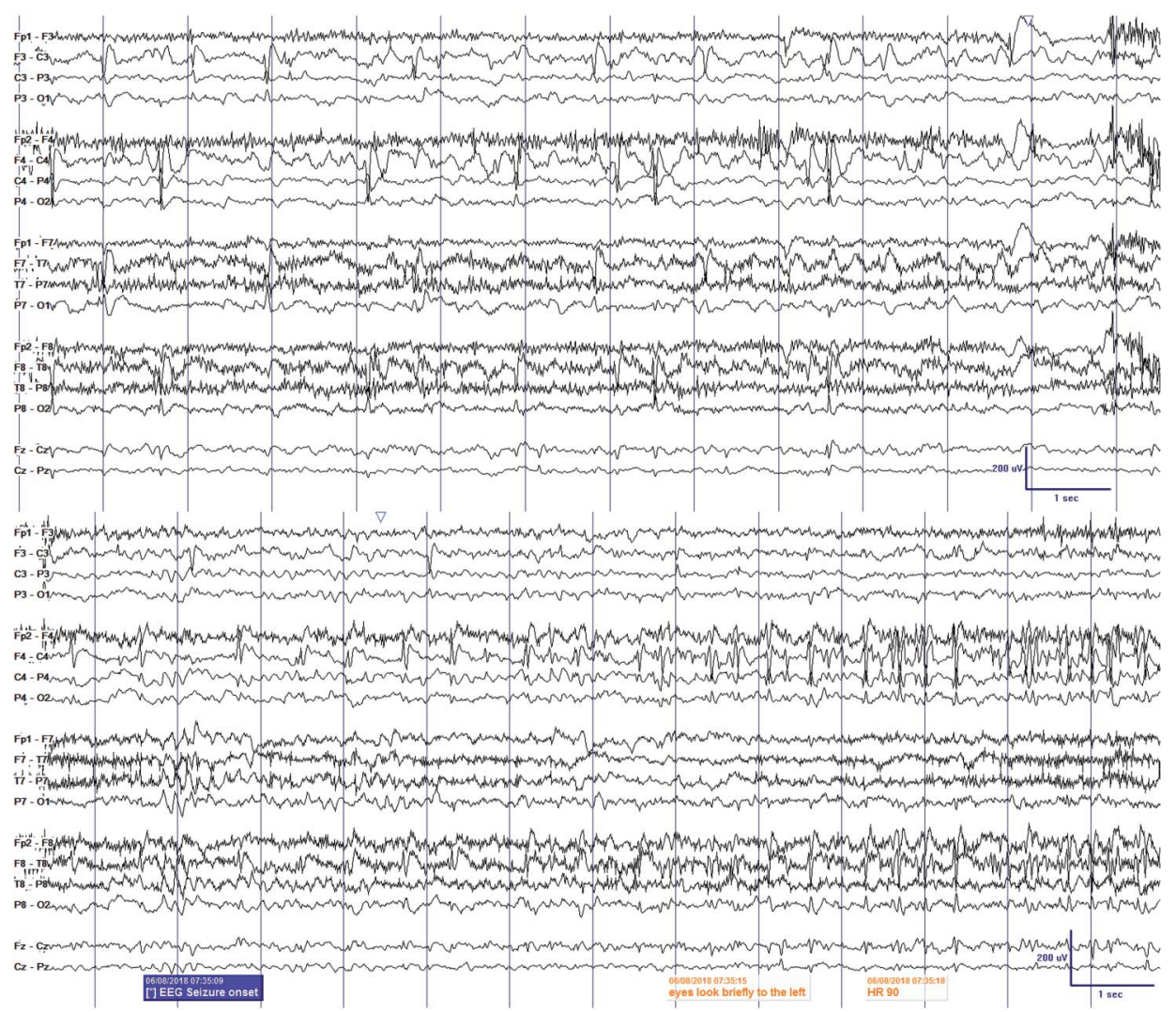

(A) Awake. (B) Seizure onset.

A 7-year-old right-handed boy with poorly controlled epilepsy presented to the epilepsy monitoring unit for further clarification of his diagnosis. Seizure onset was at 3 years with focal motor seizures of left face and arm followed by confusion and aphasia. Prominent behavioral and school difficulties were also reported. Valproic acid monotherapy $(23 \mathrm{mg} / \mathrm{kg} / \mathrm{d})$ was weaned by day 2 and a habitual event captured on day 5 (figure, video 1). Brain MRI and an epilepsy gene panel (including GRIN2A) were nonrevealing. The diagnosis was therefore consistent with atypical childhood epilepsy with centrotemporal spikes. This differs from benign rolandic epilepsy because of earlier seizure
Correspondence

Dr. Misra

smisra@luriechildrens.org
MORE ONLINE

๑ Video

$\rightarrow$ Teaching slides

links.lww.com/WNL/

B11

From the Epilepsy Center (E.S., K.M., S.N.M.), Ann \& Robert H. Lurie Children's Hospital of Chicago; and Department of Pediatrics (S.N.M.), Northwestern University Feinberg School of Medicine, Chicago, IL.

Go to Neurology.org/N for full disclosures. Funding information and disclosures deemed relevant by the authors, if any, are provided at the end of the article. 
onset, increased seizure burden, EEG with background slowing (figure) with stereotyped discharges, seizure semiology, and more prominent comorbidities. ${ }^{1,2}$

\section{Study funding}

No targeted funding reported.

\section{Disclosure}

The authors report no disclosures relevant to the manuscript. Go to Neurology.org/N for full disclosures.

\section{Appendix Authors}

\begin{tabular}{llll}
\hline Name & Location & Role & Contribution \\
\hline $\begin{array}{l}\text { Egidio } \\
\text { Spinelli, MD }\end{array}$ & $\begin{array}{l}\text { Ann \& Robert H. } \\
\text { Lurie Children's } \\
\text { Hospital of Chicago }\end{array}$ & Author & $\begin{array}{l}\text { Article } \\
\text { concept and } \\
\text { writing }\end{array}$ \\
\hline
\end{tabular}

Appendix (continued)

\begin{tabular}{llll}
\hline Name & Location & Role & Contribution \\
\hline $\begin{array}{l}\text { Khrystyna } \\
\text { Moskalyk, BS, } \\
\text { REEGT, CLTM }\end{array}$ & $\begin{array}{l}\text { Ann \& Robert H. } \\
\text { Lurie Children's } \\
\text { Hospital of Chicago }\end{array}$ & Author & $\begin{array}{l}\text { Article } \\
\text { concept and } \\
\text { clinical } \\
\text { testing }\end{array}$ \\
\hline $\begin{array}{l}\text { Sunita N. } \\
\text { Misra, MD, }\end{array}$ & Ann \& Robert H. & Corresponding & Article \\
PhD & Lurie Children's & author & $\begin{array}{l}\text { concept and } \\
\text { editing }\end{array}$ \\
\hline
\end{tabular}

\section{References}

1. Aicardi J, Chevrie JJ. Atypical benign partial epilepsy of childhood. Develop Med Child Neurol 1982;24:281-292.

2. Parisi P, Paolino MC, Raucci U, et al. "Atypical forms" of benign epilepsy with centrotemporal spikes (BECTS): how to diagnose and guide these children: a practical/scientific approach. Epilepsy Behav 2017;75:165-169. 


\section{Neurology}

\section{Teaching Video NeuroImages: Atypical childhood epilepsy with centrotemporal spikes: Seizures often discussed, rarely seen \\ Egidio Spinelli, Khrystyna Moskalyk and Sunita N. Misra \\ Neurology 2019;93;e2308-e2309 \\ DOI 10.1212/WNL.0000000000008637}

This information is current as of December 9, 2019

\section{Updated Information \&} Services

\section{References}

Subspecialty Collections

\section{Permissions \& Licensing}

Reprints including high resolution figures, can be found at: http://n.neurology.org/content/93/24/e2308.full

This article cites 2 articles, 0 of which you can access for free at: http://n.neurology.org/content/93/24/e2308.full\#ref-list-1

This article, along with others on similar topics, appears in the following collection(s):

\section{All Pediatric}

http://n.neurology.org/cgi/collection/all_pediatric

EEG

http://n.neurology.org/cgi/collection/eeg

EEG; see Epilepsy/Seizures

http://n.neurology.org/cgi/collection/eeg_see_epilepsy-seizures

Epilepsy monitoring

http://n.neurology.org/cgi/collection/epilepsy_monitoring_

Epilepsy semiology

http://n.neurology.org/cgi/collection/epilepsy_semiology

Information about reproducing this article in parts (figures,tables) or in its entirety can be found online at:

http://www.neurology.org/about/about_the_journal\#permissions

Information about ordering reprints can be found online:

http://n.neurology.org/subscribers/advertise

Neurology ${ }^{\circledR}$ is the official journal of the American Academy of Neurology. Published continuously since 1951, it is now a weekly with 48 issues per year. Copyright (O 2019 American Academy of Neurology. All rights reserved. Print ISSN: 0028-3878. Online ISSN: 1526-632X.

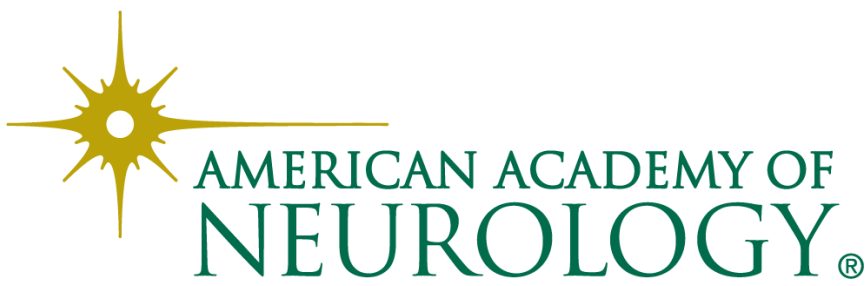

